\title{
AS INSTITUIÇÕES DA MARINHA NO RIO DE JANEIRO E A PRESERVAÇÃO DE BENS CULTURAIS
}

\author{
Miriam Benevenute Santos \\ Marcus Granato
}

DOI: https://doi.org//0265 I2/museologia.v7il 4.18390

\section{RESUMO}

Este trabalho apresenta resultados de pesquisa sobre os museus da Marinha do Brasil no Estado do Rio de Janeiro. Trata-se de pesquisa qualitativa onde a metodologia utilizada incluiu a pesquisa de fontes secundárias e primárias relacionadas ao tema e visitas técnicas aos nove espaços que foram foco da pesquisa. A Marinha do Brasil, ao longo dos anos, tem desenvolvido mecanismos para conhecer e controlar os objetos que podem ser classificados como bens culturais e que estão sob sua guarda. Os acervos identificados datam do século XVII até os anos de 1950 e se apresentam em situações de preservação diferenciadas. Em geral, percebe-se a necessidade de aprofundar o estudo sobre os mesmos de forma a propiciar sua melhor contextualização e plena apropriação pela sociedade em geral.

\section{PALAVRAS-CHAVE}

Museologia; Patrimônio cultural; Marinha do Brasil; Museus da Marinha.

\begin{abstract}
This paper presents research results on the museums of the Brazilian Navy in the State of Rio de Janeiro. It is a qualitative research where the methodology used included the search of secondary and primary sources related to the theme and technical visits to the nine spaces that were the focus of the study. The Navy of Brazil, over the years, has developed mechanisms to know and control the objects that can be classified as cultural goods and that are in its custody. The identified collections date from the XVIIth century to the 1950s and present themselves in different preservation situations. In general, it was perceived the need to deepen the study on them in order to provide their better contextualization and full ownership by society in general.
\end{abstract}

\section{KEY WORDS}

Museology; Heritage; Brazilian Navy; Navy museums. 


\section{Introdução}

A Política Nacional de Defesa (2012)' brasileira se estrutura visando preservar a "soberania e os interesses nacionais" (PND, 20I5, p.16). Dentre os Objetivos Nacionais de Defesa contidos nesse documento, está no primeiro item: "Garantir a soberania, o patrimônio e a integridade nacional” (PND, 20I5, p. I6). O termo patrimônio está aqui inserido com uma conotação que não se relaciona aos bens culturais, mas sim ao patrimônio administrativo do País.A noção de patrimônio é normalmente considerada desta forma em todas as instâncias governamentais que não têm relação direta com a Cultura.

No caso das Forças Armadas - FA, para atender à demanda relativa ao patrimônio cultural e sua preservação, se estabelecem órgãos especializados que têm como missão gerir o patrimônio cultural militar sob a sua guarda.

Na Marinha do Brasil, esta missão é da Diretoria do Patrimônio Histórico e Documentação da Marinha - DPHM, que apresenta em seu Regulamento² suas principais atribuições: "A DPHDM tem o propósito de preservar e divulgar o patrimônio histórico e cultural da Marinha, contribuindo para a conservação de sua memória e para o desenvolvimento da consciência marítima brasileira (...)" (BRASIL, 20I3).

Além disso, cabe também às FA proteger os bens culturais em momentos de conflito armado, segundo a Convenção de Haia de 1954, da qual o Brasil é signatário. Este documento reafirma a necessidade de salvaguardar os bens culturais, implementando medidas que reforcem sua proteção. $O$ segundo protocolo data de 26 de março de 1999, e vai discorrer sobre os bens culturais, as precauções e seus efeitos em caso de ataques, a proteção reforçada ${ }^{3}$ dos bens, a imunidade dos bens protegidos e dá às responsabilidades civis e criminais realizando uma leitura mais ampla no que tange à proteção do patrimônio.

As questões que motivaram as pesquisas nesta área foram sempre relacionadas à produção de conhecimento sobre os mecanismos utilizados na Marinha do Brasil para a preservação de bens culturais e a possibilidade de proteção dos artefatos que fossem identificados. $O$ sentido de preservação aqui deve ser compreendido segundo a definição de Pinheiro e Granato:

(...) qualquer ação que se relacione à manutenção física desse bem cultural, mas também a qualquer iniciativa que esteja relaciona$\mathrm{da}$ ao maior conhecimento sobre o mesmo e sobre as melhores condições de como resguardá-lo para as futuras gerações. Inclui portanto, a documentação, a pesquisa em todas as dimensões, a conservação e a própria restauração, aqui entendida como uma das possíveis ações para a conservação de um bem (PINHEIRO; GRANATO, 2012, p. 31 ).

\footnotetext{
'Disponível em: <http://www.defesa.gov.br/arquivos/estado_e_defesa/END-PND_Optimized.pdf>. Acesso em: I5 out. 2017.

${ }^{2}$ Disponível em:<https://www.marinha.mil.br/dphdm/missao >. Acesso em: 18 out 2017.

${ }^{3}$ Proteção reforçada - O protocolo de 1999 prevê a "proteção reforçada" para alguns bens culturais. Condições para o bem beneficiar-se da proteção reforçada (P2, art I0): ser um patrimônio cultural da maior importância para a humanidade; ser protegido por medidas internas, que reconheçam seu valor cultural e histórico, bem como garantam sua proteção no mais alto nível; não ser utilizado para fins militares ou para proteger locais militares, sendo que a Parte que o controla declarou oficialmente que não o utilizará para esses fins; os bens culturais aos quais o Comitê para a Proteção dos Bens Culturais em caso de Conflito Armado tenha concedido a proteção reforçada serão inscritos na "Lista de Bens Culturais sob Proteção Reforçada". (P2, art II).

Disponível em:<https://www.icrc.org/por/resources/documents/misc/5yblal.htm>.Acesso em: 18 out. 2017.
} 


\title{
O Patrimônio e os Museus Militares
}

A partir da percepção que a diversificação dos patrimônios é um movimento contínuo e que se multiplica nos últimos anos, é necessário discutir a tipologia de patrimônio que se relaciona com esta pesquisa, o patrimônio militar. Segundo Granja:

Há um patrimônio que podemos denominar exclusivamente militar e se encontra preferencialmente nos museus militares. É composto por armas de todo tipo e todas as épocas, (...) uniformes, condecorações, emblemas, apetrechos, veículos militares, embarcações e aviões de todo o tipo. Alguns deles verdadeiras joias em sua especialidade (GRANJA, 20I5, p. I25).

O patrimônio militar é constituído pelo patrimônio móvel e imóvel relacionado às Forças Armadas ${ }^{4}$ de um determinado país ou organização. Inclui construções (patrimônio imóvel), reconhecidas mais facilmente devido às suas especificidades e peculiaridades; veículos diversos como navios, aviões, carros de combate, veículos bélicos, etc. (patrimônio móvel); arsenais, fundições e fábricas militares (que se incluem também no patrimônio industrial); objetos de C\&T contidos nas instituições de ensino e nos institutos de pesquisa e desenvolvimento (PCC\&T); objetos diversos nos acervos dos museus e demais instituições militares (pinturas - representando fatos e retratos de militares, esculturas, tapeçarias, condecorações e medalhas, bandeiras, armamentos, espólios de guerra), além dos muitos acervos das bibliotecas e arquivos das Forças Armadas. $O$ variado e volumoso patrimônio cultural das Forças tem, por característica sua diversidade e multidisciplinaridade e está espalhado por todo território nacional.

Os estudos e iniciativas de preservação do Patrimônio Cultural Militar congregam muitos entusiastas e pesquisadores. As tecnologias desenvolvidas pelas Forças Armadas (FA) auxiliam na produção industrial, no campo da medicina, no campo das ciências e movimenta um grande número de pesquisadores ao redor das áreas com que trabalha. Propicia assim a constituição de ampla gama de artefatos a que se atribuem valores variados e que podem constituir patrimônio cultural. Além disso, se incluem também artefatos que têm relação direta com a cultura militar, como vestimentas, medalhas, armas, veículos militares, objetos de arte etc..

As instituições militares voltadas para a memória e preservação do patrimônio militar têm segundo Rodrigues:

\begin{abstract}
A estrutura organizacional, suporte e missão refletem a preocupação de preservar a memória militar, essencialmente na perspectiva histórica. (...) em todas as exposições, da mais elaborada a mais humilde tem um denominador comum: conservar os diferentes testemunhos e ações militares (RODRIGUES, 2005, p.04).
\end{abstract}

Por um lado, nota-se uma cultura de preservação do patrimônio material nas Forças, que não é percebido na maioria das instituições governamentais. Por outro lado, na maioria das vezes, não há especialistas suficientes para dar conta

\footnotetext{
${ }^{4}$ Instituições de cunho militar, responsáveis pela defesa do Brasil; são constituídas pela Marinha do Brasil, pelo Exército Brasileiro e pela Força Aérea Brasileira. São funções das instituições militares: assegurar a integridade do território nacional; defender os interesses e os recursos naturais, industriais e tecnológicos brasileiros; proteger os cidadãos e os bens do país; garantir a soberania da nação. Também é missão das Forças Armadas a garantia dos poderes constitucionais constituídos e, por iniciativa destes, atuar na garantia da lei e da ordem para, em espaço e tempo delimitados, preservar o exercício da soberania do Estado e a indissolubilidade da Federação. As Forças Armadas atuam sob a direção superior do Ministério da Defesa (MD), que tem a incumbência de orientar, supervisionar e coordenar as atividades desenvolvidas por essas instituições. Disponível em: <http://www.defesa.gov.br/forcas-armadas >.Acesso em: 05 mai. 2017.
} 
dessa atividade, o que muitas vezes resulta em procedimentos inadequados para a preservação desse vasto patrimônio cultural.

Dentre os diversos tipos de patrimônio nas Forças Armadas e também nas Forças Auxiliares (Polícia Militar, Polícia Civil, Corpo de Bombeiros e Guarda Municipal) pouco ou nada se fala do patrimônio imaterial. Este pode ser identificado no linguajar próprio de cada Força, nos códigos, nos comportamentos, na música, nas tradições. Essas tradições são aprendidas gradualmente, no dia-a-dia e, durante a formação e a vivência no meio militar, se tornam um elemento aglutinador pela identificação criada dentro daquele grupo. As tradições geram um sentimento de patriotismo nas tropas, mantém vivas na memória as raízes das instituições militares.A intensão é de transmissão da ideia de perenidade, de solidez. Exemplificando, a liturgia seguida nos navios e instituições de terra, gera no comportamento de bordo, uma gentileza em todos os níveis. A linguagem produzida por estas tradições é entendida por todos: o apito avisando das fainas rotineiras, o hastear da bandeira, o toque do sino, as gírias marinheiras, a postura diante dos mais antigos.

A preservação da cultura militar também é uma forma de legitimação do grupo, de poder, com aponta Fonseca no trecho a seguir:

Preservar traços de sua cultura é também, hoje sabemos, uma de-
monstração de poder. Pois são os poderosos que não só conse-
guem preservar as marcas de sua identidade como, muitas vezes,
chegam até a se apropriar de referências de outros grupos (...)
ressemantizando-as na sua interpretação (FONSECA, 200 I, p.l I4).

Os objetos militares, particularmente os ligados à guerra, quando exibidos, provocam no público determinado conjunto de percepções e respostas de acordo com a linguagem com que são expostos. $O$ discurso pode ter um cunho bélico, tecnológico ou até mesmo estético.

Outro fato a se observar nas coleções que compõem o patrimônio militar é que, como característica, as peças de pinturas e esculturas ligadas aos feitos militares constituem acervo de notável qualidade artística. Esta realidade se dá pois para confecção destas obras, em geral, foram contratados artistas expoentes das épocas em que os fatos se deram. Essa parte do acervo permite construir uma narrativa, um histórico dos fatos, impregnados de beleza estética.

Porém, o Patrimônio Militar não é exclusividade das FA. Ele está contido em muitas coleções de Museus Históricos, Museus de Armas e coleções privadas.A diferença se dá no trato recebido por estes, como afirma Almeida:

\footnotetext{
(...) É certo que os acervos e coleções militares não estão apenas em museus, mas estas instituições se organizam internamente em torno de seus acervos - de objetos, imagens, textos- e se definem mesmo por referência aos trabalhos que se desenvolvem com acervos. Por isso mesmo é nestas instituições que se pode esperar sejam os acervos militares, como outros acervos, mais estudados, melhor preservados e colocados à disposição do público (ALMEIDA, 2008, p.65).
}

De uma forma geral, o patrimônio militar é bem documentado e catalogado, graças à cultura patrimonialista existente nas Forças, como já mencionado, e aos muitos militares e civis que vêm, ao longo dos anos, se preocupando com este valioso acervo cultural que pertence ao povo brasileiro.

Os museus são instituições determinantes para a preservação do patrimônio militar pois têm a função da preservação em sua gênese. Nesse contexto, 
cabe destacar que, em 17 de outubro de 2013, foi publicado o Decreto 8. $124^{5}$, regulamentando dispositivos da Lei II.9046, de I4 de janeiro de 2009, que institui o Estatuto de Museus. O Decreto mencionado é de grande relevância, pois, além de caracterizar a existência de bens culturais musealizados e passíveis de musealização, determina que ambos podem ser declarados de interesse público, o que protege especialmente os bens fora dos museus, já que aqueles declarados de interesse público estão submetidos às mesmas exigências dos bens musealizados.

Pelo mencionado, cabe definir e discutir as instituições museológicas no âmbito das Forças. Segundo Kirouac:

Por milênios, os seres humanos conservaram objetos relacionados à guerra. Infelizmente, se trouxeram de volta como troféus, lembranças ou artefatos como potencial museológico, esses objetos que testemunham o conflito não tiveram nenhum efeito notável na decisão de ir à guerra (...) $\bigcirc$ museu militar como instituição que preserva o tangível da Memória das Guerras, tem o dever de fazer com que esses objetos testemunhem e de enviar uma mensagem dos combatentes: 'Não há mais guerras!'. Os museus militares tem a responsabilidade de trabalhar para paz duradoura (KIROUAK, 2009, p. 22-23 apud TEIXEIRA, 20I I, p.20).

Teixeira trabalha o museu militar como um órgão cultural que depositário de um espólio-militar o valoriza, expõe e o processa museologicamente (TElXEIRA, 20II, p.396).

Os museus militares em sua maioria são criados para celebrar vultos e fatos da história de suas instituições fundadoras e preservar a materialidade que os documenta. Os valores atribuídos aos objetos que constituem suas coleções, relacionados a seu discurso e a sua apresentação podem, segundo Appelbaum (2007), serem entendidos como Valor de Pesquisa, por fornecerem "informações que não sejam próprias do objeto”, Valor de Raridade, devido à existência de poucos exemplares, Valor Histórico, pois auxiliam na narrativa dos fatos relativos à história militar, e ainda como Valor Comemorativo, pois muitos destes objetos são criados ou associados a datas ou eventos que memoram os feitos das Forças.

Ao analisar os museus militares, Teixeira nos apresenta que:

As colecções que constituem os acervos dos museus militares (...) são consequência do processo histórico de criação (...). Os acervos destes museus destacam-se, no panorama museológico, pela especificidade das suas colecções heterogéneas que incluem objectos originais, réplicas e maquetas que se relacionam com factos históricos mais ou menos marcantes. São, na sua maior parte, objectos funcionais que estiveram em uso na sua época, tais como armas e munições, falerística, instrumentos musicais, traje militar, viaturas militares, equipamento militar, instrumentos científicos, entre outros, que reflectem diferentes níveis dos seus contextos. Em menor percentagem registam-se nas colecções artefactos do âmbito da pintura, da escultura, da fotografia, da gravura, do desenho, que têm em comum a representação de temáticas e a história militar. Estas colecções provenientes na sua maior parte de transferências de Unidades/Estabelecimentos/Órgãos do Exército ou de doações de militares ou de seus familiares, não são documentos neutros, pois

\footnotetext{
${ }^{5}$ Disponível em: <http://www.planalto.gov.br/ccivil_03/_Ato20I I-20I4/20I3/Decreto/D8I24.htm>.Acesso em: 06 mai. 2017.

6 Disponível em: <http://www.planalto.gov.br/ccivil_03/_ato2007-2010/2009/lei/II I904.htm>. Acesso em: 06 mai. 2017.
} 
foram seleccionados a partir de um leque vasto de escolhas possíveis e por isso foram condicionados pelos colectores respectivos (independentemente da modalidade de incorporação) ou profissionais dos museus que agiram de acordo com o seu contexto histórico, político e ideológico (TEIXEIRA, 20I I, p. 106).

Embora sejam bastante específicas, essas instituições, se incluem na categoria dos museus históricos, pois suas coleções narram as atividades militares de forma cronológica, mas também se articulando com os museus de ciência e tecnologia, pois as Forças Armadas possuem várias pesquisas e desenvolvimentos nestas áreas. Com uma fala espelhada nos museus da MB, Bittencourt e Loureiro articulam a respeito de museus:

\footnotetext{
Entre as múltiplas funções a que se destinam os museus, uma delas é permitir a reflexão acerca do que se construiu no passado e do que se espera para o futuro.
}

Por óbvio, a conexão dessas duas dimensões temporais - passado e futuro - se estabelece pelo presente, que somente pode comportar consciência do valor da trajetória de grupos e instituições se for perpassado por sua história. Enchem o presente de significado. Promovem reflexão e perspectivas para o futuro. E, ainda, advertem que as ações do presente são fundamentais para se atingir o futuro desejado. Quem compreende bem a dinâmica da História torna-se responsável pelos seus atos (BITTENCOURT; LOUREIRO, 20I2, p.2I).

No Brasil, assim como na Europa, os museus militares abrem ao público no século XIX e são marcados por um caráter romântico que se reflete nos objetos expostos: lembranças, troféus, recordações históricas e culto aos heróis (HERNÁNDEZ, 2006, p.09).

Das mais variadas formas de apresentação museográfica, estas instituições estão instaladas em prédios ou complexos militares, trabalhando com o público em geral e apresentando inúmeros acervos. Sua terminologia incorpora dois conceitos: museu e militar. O International Coucil of Museums (ICOM) define museu como:

... instituição permanente sem fins lucrativos, ao serviço da sociedade e do seu desenvolvimento, aberta ao público, que adquire, conserva, investiga, comunica e expõe o patrimônio material e imaterial da humanidade e do seu meio envolvente com fins de educação, estudo e deleite. ${ }^{7}$

E, baseado na definição do ICOM,André Kirouac (2009, p.22) propõe uma adaptação para museus militares:

Um museu militar é uma instituição permanente, sem fins lucrativos, que adquire, preserva, pesquisa, interpreta e apresenta as evidências tangíveis e intangíveis da história militar e serve a sociedade, elevando a consciência do impacto da guerra e dos valores pacifistas (KIROUAK, 2009, p.22, apud TEIXEIRA, 20I I, p.20).

A função museológica da instituição museu militar seria a de servir à sociedade "através da sensibilização para o impacto da guerra e dos valores pacifistas" (KIROUAK, 2009, p.22, apud TEIXEIRA, 20I I, p.20). O seu discurso precisa transmitir, na atualidade, às gerações de agora e futuras, as vivências dos militares pela paz no passado.

No ICOM, o comitê onde os museus e coleções militares estão inseridos

${ }^{7}$ Disponível em:<http://icom-portugal.org/documentos_def, I29, I6I, lista.aspx>.Acesso em:06 mar. 2018. 
é o International Committee for Museums and Collections of Arms and Military History $^{8}$ - ICOMAM. Os profissionais reunidos neste comitê desenvolvem pesquisas sobre o tema no cenário museológico e da museologia e incentivam o estudo e a conservação de armas, armaduras, artilharia, fortificações, uniformes, etc.. Seu objetivo é demonstrar de que forma as armas e a história militar são parte do patrimônio cultural da humanidade. Importante dizer que a Marinha do Brasil e a Força Aérea são filiados ao ICOMAM e que dois dos encontros desse Comitê foram sediados pela MB em 2008 e 2013.

Segundo Gutiérrez, os museus militares, assim como os demais museus,

Desde suas origens, eles baseiam-se na salvaguarda dos seus fundos. $O$ estado de conservação dos diferentes objetos que guarda um museu é fundamental porque, sobre esses mesmos elementos, apoia-se o desenvolvimento de todas as tarefas paralelas, mas igualmente primordial, que dá significado ao Museu de hoje. $\bigcirc$ estudo e pesquisa, documentação, divulgação, etc., bem como a interação com outros escritórios e organismos, são atividades que são suportadas, diretamente ou indiretamente, nas peças e coleções que possui, ou na qual trata um museu particular` (GUTIÉRREZ, 20I0, p.33, tradução nossa).

A conservação destes acervos se torna facilitada pelo grau de conhecimento que temos deles, especialmente sobre que tipos de material foram usados, a que condições estão expostos ou armazenados, qual a trajetória que tomaram.

Quanto à gestão destas instituições Hernández afirma que:

Geralmente, estes museus militares tem sido geridos por órgãos correspondentes do Ministério da Defesa, e estão financiados com fundos públicos. A maioria deles são dirigidos por militares que possuíam uma excelente formação militar e eram conhecedores e estudiosos das coleções, em alguns casos careciam de uma formação museológica básica que os impedia de desenvolver um eficiente trabalho de difusão na hora de expor as coleções ${ }^{10}$ (HERNÁNDEZ, 2006, p. I3, tradução nossa).

Nas duas últimas décadas, tem-se notado um movimento em busca de profissionalização não só da organização e realização das exposições, bem como no processamento técnico dos acervos militares, através da inclusão de museólogos nos quadros de carreira e temporários. As FA têm acolhido em suas fileiras quase que anualmente profissionais museólogos, conservadores e restauradores para lidar com a diversificada gama de objetos, musealizados ou não, contidos nas suas instituições. Esta mudança aponta para a preocupação das FA com o trato dos acervos.

A importância da inclusão do profissional museólogo nas FA influencia diretamente também na conservação dos bens imóveis tombados nos diversos

\footnotetext{
${ }^{8}$ Disponível em: <http://icom.museum/the-committees/international-committees/international-committee /international-committee-for-museums-and-collections-of-arms-and-military-history/>.Acesso em:06 mar. 2018.

9 "Desde SUS orígenes, tienen como base la salvaguarda de sus fondos. El estado de conservación de los diferentes objetos que custodia um museo es primordial ya que, sobre estos mismos elementos, se apoyan y se desarrollan todas las labores paralelas, pero igualmente primordiales, que dan sentido al museo de hoy em día. El estudio e investigación, La documentación, La divulgación, etc, así como La interacción com otras sedes y organismos, son actividades que se apoyan, directa o indirectamente, em lãs piezas y colecciones que posee o sobre las que trata un determinado museo".

10 "Generalmente, estos museos militares han sido gestionados por loscorrespondientes ministérios de Defensa y están financiados confondos públicos. La mayoría de ellosestaban dirigidos por militares que, si bienposeían uma excelente formación militar y eranconocedores y estudiosos de lascolecciones,enalgunos casos carecían de una formación museológica básica que les impedia desarrollar uma eficiente labor de difusiónnala hora de exponerlascolecciones".
} 
níveis (municipal, estadual e federal), pois muitos dos espaços ocupados pelas Forças são construções históricas ou estão inseridas em áreas de preservação. No que se refere à conservação dos bens móveis, nas FA Brasileiras a presença de profissionais da área de museologia é de suma importância para a conservação e preservação destes bens.

Outro ponto a ser observado é a ressonância destas instituições no cenário nacional dos museus, pois o público atraído pelas coleções expostas é bastante expressivo.

Exposições mais modernas e com uma linguagem museográfica atraente, atividades educativas que trabalhem com o tema da exposição, estimulando o público a interagir de formas diversas com os espaços expositivos e desenvolvendo atividades em datas comemorativas, produção de exposições temporárias, itinerantes e virtuais têm auxiliado na divulgação das atividades destas instituições.

Leve-se em conta também que boa parte dos museus militares está instalada em prédios históricos, com arquitetura por si só ímpar; no caso da MB, o Museu Naval e a Ilha Fiscal, promovendo maior interesse do público, funcionando o edifício como um primeiro atrativo. Junte-se o fato de que alguns destes locais dialogam em tal harmonia com os acervos expostos que, por vezes, não é possível pensar um sem o outro, auxiliando a narrativa expositiva.

Quanto à coleta de objetos, cabe mencionar que os museus ligados às FA recolhem continuamente objetos ligados à sua história, o que provoca a necessidade constante de renovação e crescimento nas instituições de guarda e no trabalho de museólogos, conservadores, arquivistas e bibliotecários. Esta dinâmica se dá por conta da consciência e interesse dos profissionais desses museus que percebem o envolvimento das Forças nas mais diversas atividades a que são suscitadas e, de forma continuada, exigindo uma atitude pró ativa para que os acervos sejam atualizados e permaneçam sendo representativos de todas essas atividades.

\section{A Marinha do Brasil e os Bens Culturais}

$\mathrm{Na}$ Marinha do Brasil, como já mencionado, a missão da preservação de bens culturais é da Diretoria do Patrimônio Histórico e Documentação da Marinha - DPHM. Este movimento de salvaguardar os objetos de valor cultural na MB tem início após a Guerra do Paraguai, quando os objetos que foram apreendidos documentavam os fatos relacionados à Guerra, formaram o acervo do Museu Naval inaugurado em $1868^{\prime \prime}$.Após alguns anos de funcionamento, este foi fechado ${ }^{12}$, e somente reaberto na década de 1970.

A preocupação com a salvaguarda dos objetos sempre esteve presente nas atividades da então Diretoria do Patrimônio Histórico e Cultural da Marinha que indicava alguns objetos a serem preservados quando da desativação das OM, sejam elas de terra ou navios.

Em um processo de amadurecimento, a DPHCM, juntamente com o SDM, receberam a tarefa de criar uma diretriz que normatizasse, desse orientação e criasse um meio de controle efetivo sobre os bens culturais sob a guarda da MB.

\footnotetext{
"Criado pelo Decreto $n^{\circ} 4.116$, de 14 de março de 1868. Disponível em: <http://www2.camara.leg.br/ legin/fed/decret/|824-|899/decreto-4| |6-I4-marco-|868-553330-norma-pe.html>. Acesso em: I8 out. 2017. Sua inauguração, entretanto, se deu somente dezesseis anos depois, em 24 de março de 1884, com a presença do Imperador Dom Pedro II, de seus ministros e de uma significativa presença de oficiais.

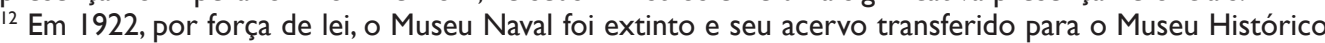
Nacional, criado neste mesmo ano durante o governo de Epitácio Pessoa:"Art 83. Serão transferidos para o Museu Histórico Nacional: (...). Os quadros históricos e mais objetos de caráter histórico que formam o Museu da Marinha e o Museu Militar"(BRASIL, Decreto n. I5.596, de 2 agosto de 1922, 1922).
} 
Esse documento deveria esclarecer a qualquer administrador ou gestor quais as ações necessárias para exercer uma guarda eficaz sobre os bens que estavam sob sua responsabilidade.

A primeira edição do documento foi denominada SGM-50I - Normas para Gestão de Bens Culturais da Marinha do Brasil (2004). Além de dar orientações, o documento fornece definições que têm como objetivo auxiliar no trabalho desenvolvido pelas diversas $O M$ espalhadas pelo território nacional. Esta norma foi de grande impacto na $\mathrm{MB}$, criando novos parâmetros de controle dos bens culturais, pois as OM deveriam tomar ações como elaborar um livro de registro, registrar os bens culturais que possuíssem, preencher uma ficha para cada objeto e fazer o registro fotográfico, sempre conforme os modelos do anexo do documento, e imprimir duas cópias; uma ficaria sob a guarda da OM, como gestor dos bens, e a outra deveria ser enviada para a DPHCM.

A norma batizada como SGM-50 I, criava também uma demanda de envio de relatórios e mensagens informando se houve ou não alteração nos bens culturais das OM e seu estado de conservação, provocando uma rotina de visita a estes objetos. A intenção foi a de cultivar nos gestores uma preocupação com os objetos. Segundo Stori e Maranhão,

A importância da gestão dos bens culturais pelas organizações públicas e privadas tornou-se um fator estratégico na contemporaneidade. Além de fortalecer laços culturais, a gestão desses bens resgata o exercício da cidadania, amplia as relações territoriais e possibilita a defesa de conhecimentos (STORI; MARANHÃO, 2016, p.02).

Devido ao afastamento permitido pelo passar do tempo, hoje é possível constatar que este documento possuía grande potencial de impacto mas foi insuficientemente trabalhado. Seja pelo prazo dado, pela ignorância em relação ao tema, seja pela ineficiência no que tange à não recepção de orientação para as $O M$ que não trabalham com assuntos culturais. $O$ que se pode concluir é que, embora tenha sido um grande passo no controle dos bens culturais na área naval, neste primeiro momento, a apatia com relação ao processo predominou e não foram produzidas as informações necessárias para um controle efetivo. Para Teixeira (20II), "uma gestão efectiva das colecções deve caracterizar por ser pró-activa em vez de reactiva” (TEIXEIRA, 20I I, p. 42).

Portanto, é provável que os resultados apresentados estejam subdimensionados o que nos leva a pensar o quanto ainda é necessário esclarecer e informar para formar uma conscientização sobre o que seja o bem cultural na MB.

Após cinco anos, a publicação SGM-50I foi revisada e ganha uma versão mais ampliada. Esta revisão foi motivada pela necessidade de adequação de linguagem e, também, pela necessidade de inclusão de outros assuntos relativos à gestão dos bens culturais na Marinha, devido à reestruturação da Diretoria do Patrimônio Histórico e Comunicação da Marinha (DPHCM). Extinta em juIho de 2008, passa suas funções para o Serviço de Documentação da Marinha (SDM) que é renomeado como Diretoria do Patrimônio Histórico e Documentação da Marinha (DPHDM).

Após a implantação da primeira revisão do documento SGM-50I, a DPHDM verificou a necessidade de oferecer treinamento para o pessoal que trabalhava ou viria a trabalhar com a gestão dos bens culturais na Marinha. Fossem eles militares ou civis. Criou-se assim, o Curso de Gestão de Bens Culturais na Marinha.

O primeiro curso foi ministrado em 2010 . Sua ementa tem como objeti- 
vo geral "Suplementar a habilitação técnico-profissional de militares e civis para o trato com os bens culturais que compõem o acervo da MB, contribuindo com a melhoria na conservação, exposição e guarda dos objetos culturais da MB."

O curso, composto por uma parte teórica e outra prática, onde os alunos eram levados a conhecer mais profundamente a Gestão de Bens Culturais na Marinha do Brasil, recebendo orientações sobre as ações e providências necessárias para uma boa gestão e aulas práticas de preenchimento das informações da Fichas. A parte prática era composta também de higienização e acondicionamento de objetos comuns ao dia-a-dia das OM.

A realização do curso se deu ainda nos anos de 2012, 2014 e 2017. Após a implantação, a Divisão de Acervo, responsável pela Divisão de Conservação e Restauração da DPHDM, pode perceber um número menor de pedidos de restauro e intervenção nos acervos das demais OM e mesmo uma preocupação destas em acionar a DPHDM no caso de precisar de assessoria quanto ao estado de conservação de um bem cultural.

No ano de 2012, atendendo a esta necessidade e outras apresentadas, é realizada a segunda revisão da SGM-50I. Foi incluído o capítulo que vai apresentar as Normas para Aquisição e Alienação de Bens, que estabelece regras para definir os princípios e procedimentos referentes à aquisição e alienação do acervo museológico das $\mathrm{OM}$, bem como orienta as mesmas a elaborarem uma ordem interna sobre o assunto para seus acervos.

A importância desta inclusão no documento se dá pois, até então, os bens culturais recebiam quase que o mesmo tratamento de uma cadeira do setor administrativo, por exemplo. A norma da Marinha que rege os bens patrimoniais não possui nenhum item que inclua os bens culturais, logo a alienação dos mesmos não passava por uma avaliação técnica competente, o que poderia vir acarretar um equívoco no caso de uma alienação de um bem passível de restauração.

No ano de 2017 foi apresentada uma nova versão, que aguarda aprovação, onde prevê atualização e modernização dos sistemas de controle dos bens culturais dentro da MB.

\section{Os Museus da Marinha no Rio de Janeiro}

\section{Museu da Escola Naval ${ }^{13}$}

O Museu da Escola Naval foi inaugurado em 1962 e, segundo a placa de apresentação exposta no local, tinha o objetivo de recolher objetos de importância histórica para a Escola. Está instalado na Ilha de Villegagnon.

A documentação é composta por um livro de registro de objetos iniciado na década de 1970, mas descontinuado no final dos anos de 1980. No ano de 2017 o EN recebe em suas fileiras um oficial na especialidade de Museólogo que assume as atividades do Museu.Seguem abaixo imagens da área expositiva do Museu da Escola Naval (Figuras I e 2).

\section{Espaço Cultural do Colégio Naval ${ }^{14}$}

Situado em Angra dos Reis nas dependências do Colégio Naval, o Espaço Cultura foi inaugurado em janeiro de 1999 passando a ocupar a antiga área dos alojamentos dos alunos, onde ficavam os vestiários e armários. Neste espaço, fo-

\footnotetext{
${ }^{13}$ Disponível em: <https://www.marinha.mil.br/en/>

${ }^{14}$ Disponível em: <https://www.marinha.mil.br/cn/>
} 

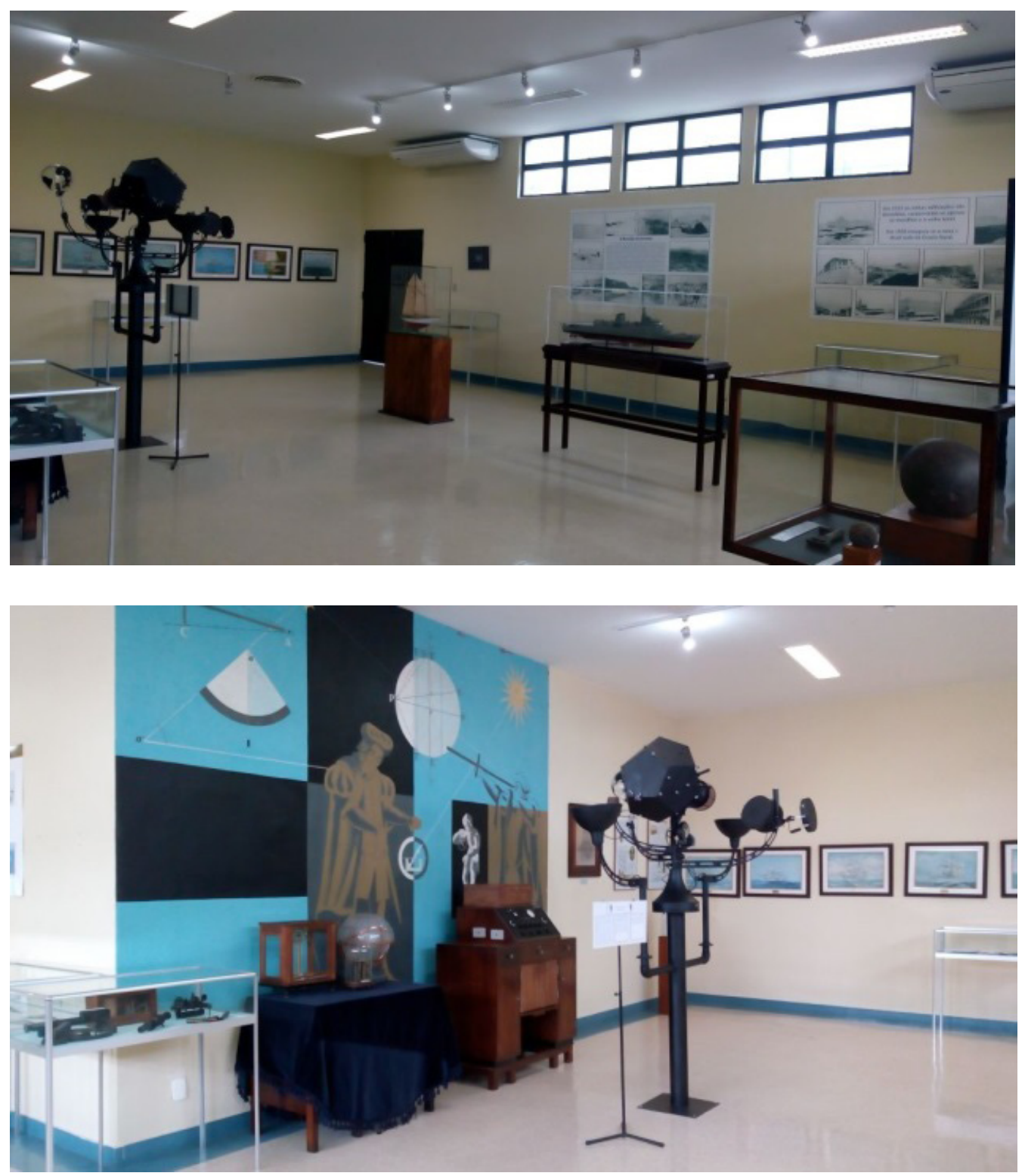

Figuras I e 2 - Imagens da área expositiva do Museu da Escola Naval.

Fotos: Miriam Benevenute Santos, 2017

ram expostas peças que compunham não só os alojamentos, mas também salas de aula. Colocou-se ali as condecorações e diplomas recebidos pelo Colégio, os "quadros dos ex-comandantes, dos alunos que alcançavam o Prêmio de Honra ao Mérito Excepcional” (FROTA, 200 I, p. 69) e o morteiro do século XVIII que antes ficava ao tempo. No Espaço Cultural também estão em exposição Objetos de Ciência e tecnologia e maquetes de embarcações.

\section{Museu Naval ${ }^{15}$}

Entre os museus subordinados a Diretoria do Patrimônio Histórico e Documentação da Marinha - DPHDM, o mais antigo é o Museu Naval, e a história de sua criação perpassa a da própria Diretoria.

Criado em plena Guerra do Paraguai, pelo decreto n 4.116 , de 14 de

\footnotetext{
${ }^{15}$ Disponível em: <https://www.marinha.mil.br/dphdm/museus/museu-naval >
} 
março de 1868 (BRASIL, I868), por iniciativa do Visconde de Outro Preto, o Museu Naval tinha como finalidade receber e arrecadar todos os objetos cuja conservação interessasse à Armada Nacional ${ }^{16}$ : objetos que retratassem o poderio bélico da Marinha e a importância desta força para a soberania nacional, bem como para a manutenção da unidade territorial; objetos que haviam sido reunidos na Guerra contra Oribe e Rosas ${ }^{17}$ e estavam já surgindo com a Guerra do Paraguai. E também objetos de personalidades consideradas importantes na história naval nacional. Dentre os objetos recolhidos e expostos no Museu, estavam sinos que foram apreendidos, armamentos, uniformes, figuras de proa dos navios usados nos conflitos, medalhas, condecorações e pinturas alusivas as batalhas e aos seus personagens.

Sua inauguração, entretanto, se deu somente dezesseis anos depois, em 24 de março de 1884 , com a presença do Imperador Dom Pedro II, de seus ministros e de uma significativa presença de oficiais. Segundo nota no Jornal do Comércio de 25 de março de 1884:
(...) logo à entrada examinou Sua Majestade a corrente que fechava o rio Paraguai, em frente às baterias de Humaitá, e sobre a qual passou a Divisão ao mando do chefe Delfim; duas chapas de cou- raça dos encouraçados Barroso e Brasil, ambas com depressões profundas e a segunda atravessada por bala; e um troféu de armas paraguaias, entre as quais se notava uma peça de arma lisa transfor- mada em raiada pelos paraguaios, e oferecida ao Museu pelo Sena- dor Silveira da Mota; duas balas de 10 polegadas e cinco calibres do Javari e diversas armas (JORNAL DO COMÉRCIO, 1884).

Um dos exemplos de objetos que foram expostos por ocasião da inauguração do Museu e que é de grande representatividade do período da Guerra do Paraguai, é a corrente que fechava o Rio Paraguai durante a Batalha de Humaitá.

Em 1890, pelo Decreto ${ }^{\circ}$ 363, de 26 de abril, são unidos a Biblioteca e - Museu em uma só diretoria (BRASIL, 1890). Novas instalações do Museu são inauguradas em II de junho de 1898, na Rua Conselheiro Saraiva no 10/12 no andar térreo, centro do Rio de Janeiro. Sua coleção continha 402 objetos diversos e, segundo o texto histórico e descritivo do Museu, contido no processo de tombamento do prédio, "eram atestados vivos e gloriosos dos feitos da nossa Marinha, também representados por uma coleção de quadros de valor inestimável" (RIO DE JANEIRO, 1990, p.8). Com a incorporação de objetos procedentes da Guerra do Paraguai, a coleção do Museu passa por uma grande expansão, não sendo seu prédio suficiente para abrigar suas coleções. Assim, em 1907, o Museu foi transferido para o prédio da Rua Dom Manoel, ficando o mesmo unido fisicamente à biblioteca e ao arquivo (GAMA, 20I3). Este prédio, que abriga o museu ainda hoje, é um edifício construído em 1900, de estilo eclético, de três pavimentos e foi ocupado inicialmente por diversas repartições navais: o Clube Naval, o Conselho do Almirantado, a Consultoria Jurídica da Marinha e a Escola de Guerra Naval (BRASIL, 20I7), como ilustra a Figura 3.

Após uma reforma administrativa em I9II (BRASIL, 197?), o arquivo foi separado da biblioteca e do Museu.

Em 1922, por força de lei (BRASIL, 1922), o Museu Naval foi extinto e seu acervo transferido para o Museu Histórico Nacional, criado neste mesmo ano durante o governo de Epitácio Pessoa, como mostra o artigo do Decreto $\mathrm{n}^{\circ}$.

\footnotetext{
${ }^{16}$ Grupamento de navios armados, pertencentes ao Estado e incorporados à Marinha de Guerra. (CHERQUES, 1999, p.67)

${ }^{17}$ Guerra entre Argentina e Brasil lutaram pela influência no Uruguai e hegemonia na região do Rio da Prata entre os anos de I85I a I852 (BRASIL, 20I5).
} 


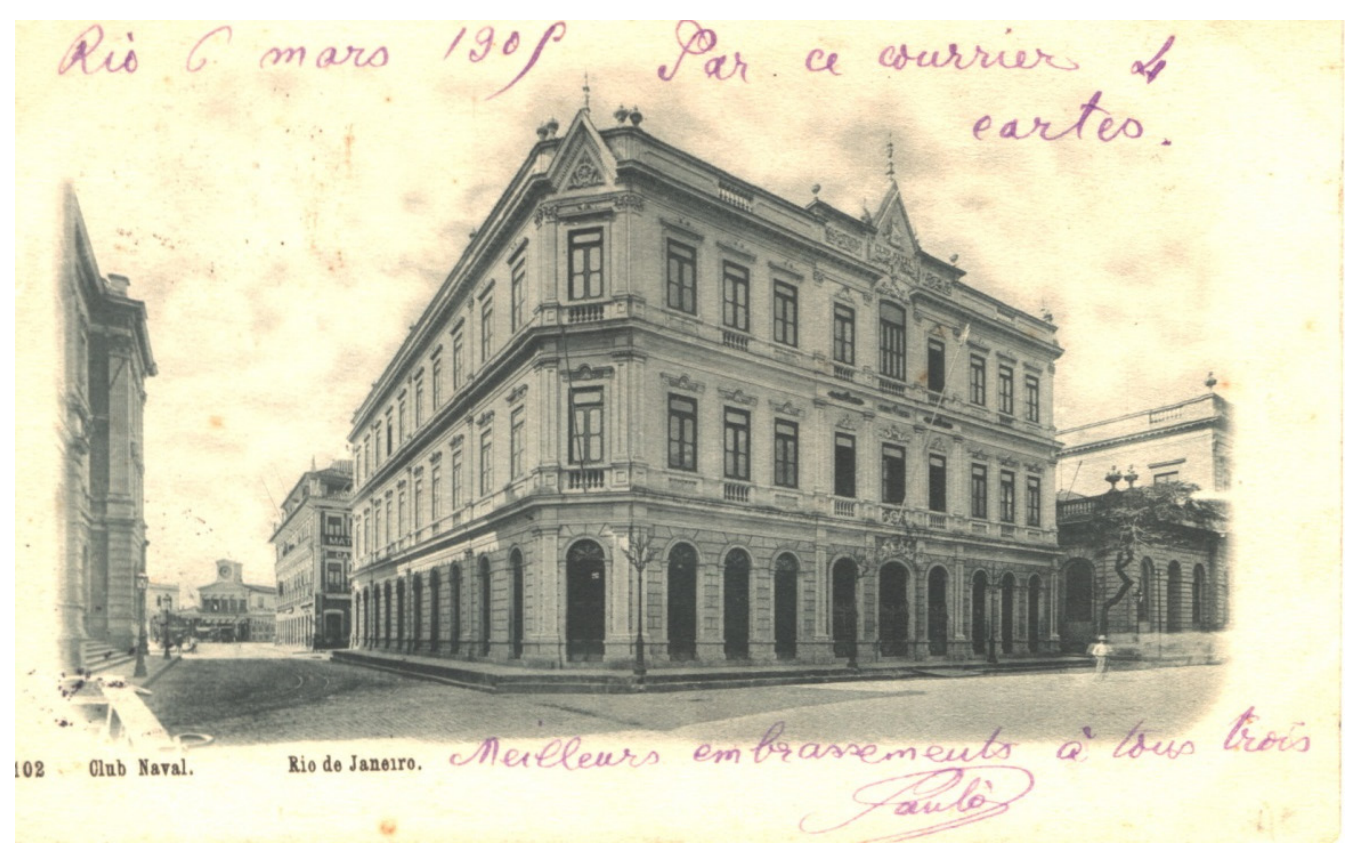

Figura 3 - Cartão Portal com imagem do então Clube Naval que passou a ser Museu Naval

Foto:Acervo: DPHDM- Arquivo da Marinha

15.596, de 2 agosto de 1922, no trecho destacado a seguir:

Art 83. Serão transferidos para o Museu Histórico Nacional: (...)

4. Os quadros históricos e mais objetos de caráter histórico que formam o Museu da Marinha e o Museu Militar; (BRASIL, 1922).

Observa-se aqui que o decreto que extingue o Museu da Marinha, também extingue o Museu Militar que pertencia ao Exército, e havia sido reinaugurado três meses antes pelo Ministro da Guerra, Dr. João Pandirá Calógeras ${ }^{18}$.

O prédio da Rua Dom Manoel foi então desocupado em 1934 e entregue ao recém-criado Ministério da Educação e Saúde Pública, para instalação de sua sede. Em 1943, o imóvel passa para o Ministério da Justiça onde foi instalado o Pretório Civil e depois varas criminais (BRASIL, 197?).

Logo após a extinção do Museu Naval, pensou-se na criação de outro museu, já que a Marinha ainda contava com inúmeras peças de interesse histórico que poderiam constituir um novo acervo. Este movimento provoca a transferência deste acervo para a Biblioteca da Marinha, sob a coordenação do Estado Maior da Armada, que evolui para a Divisão de História Marítima e esta, sucessivamente, para Serviço de Documentação da Marinha e finalmente para Serviço de Documentação Geral da Marinha - SDGM. Todas estas alterações ocorrem a partir de 01 de junho de 1939 (BRASIL, 2003).

Com a criação de um novo órgão de cultura tornava-se necessário um local apropriado para abrigar a instituição, que estava precariamente instalada. Várias tentativas foram feitas para se obter um espaço definitivo que abrigasse o SDGM, até que, em 1964, o Almirante Levy de Araújo Paiva Meira, então di-

\footnotetext{
${ }^{18}$ Histórico disponível em: <http://www.fortedecopacabana.com/museu-historico-do-exercito.html>.
} 
retor do Serviço, faz-se ouvir pelos órgãos oficiais, inclusive pela Diretoria do Patrimônio da União quanto à possibilidade da devolução do prédio da Rua Dom Manoel I5, para instalação do Serviço. É o que acontece em 1967, sendo o referido prédio cedido mediante convênio e sua permissão de uso pela Marinha é assinada em I4 de dezembro de 1970 (RIO DE JANEIRO, I980).

As novas instalações do Serviço de Documentação Geral da Marinha foram inauguradas em 10 de agosto de 1972 e reunindo os seguintes departamentos: a Biblioteca, o Museu Naval e Oceanográfico, o Arquivo Histórico e Administrativo, o Departamento de História Naval e Marítima, Publicações para a divulgação de Ciências Exatas, Tecnologia, História e dos Atos Administrativos e Serviço de Fotografia e Microfilmagem (BRASIL, 2003). A Figura 4, a seguir, apresenta uma imagem do dia da reinauguração do Museu Naval e Oceanográfico, em 1972.

Uma equipe constituída pelos alunos da Escola Superior de Museologia Fernando Menezes de Moura, Elza Maria Brum Arruda, Nice Mandarino, Regina F. de Mendonça Furtado e Terezinha Basbal, sob a coordenação do professor Affonso Celso Villela de Carvalho, desenvolveu um trabalho sistemático de levantamento, pesquisa do acervo, catalogação, tombamento e preservação das peças, além do planejamento e organização das exposições. Em relatório encontrado, consta que em dois meses de trabalho foram classificadas "de acordo com os mais modernos processos de técnica museológica"|9 1.200 peças do acervo (BRASIL, 197?).

Quando da reinauguração, o Museu Naval e Oceanográfico, nome que passa a ter, contava com seis salas dedicadas à Guerra do Paraguai, equipamen-

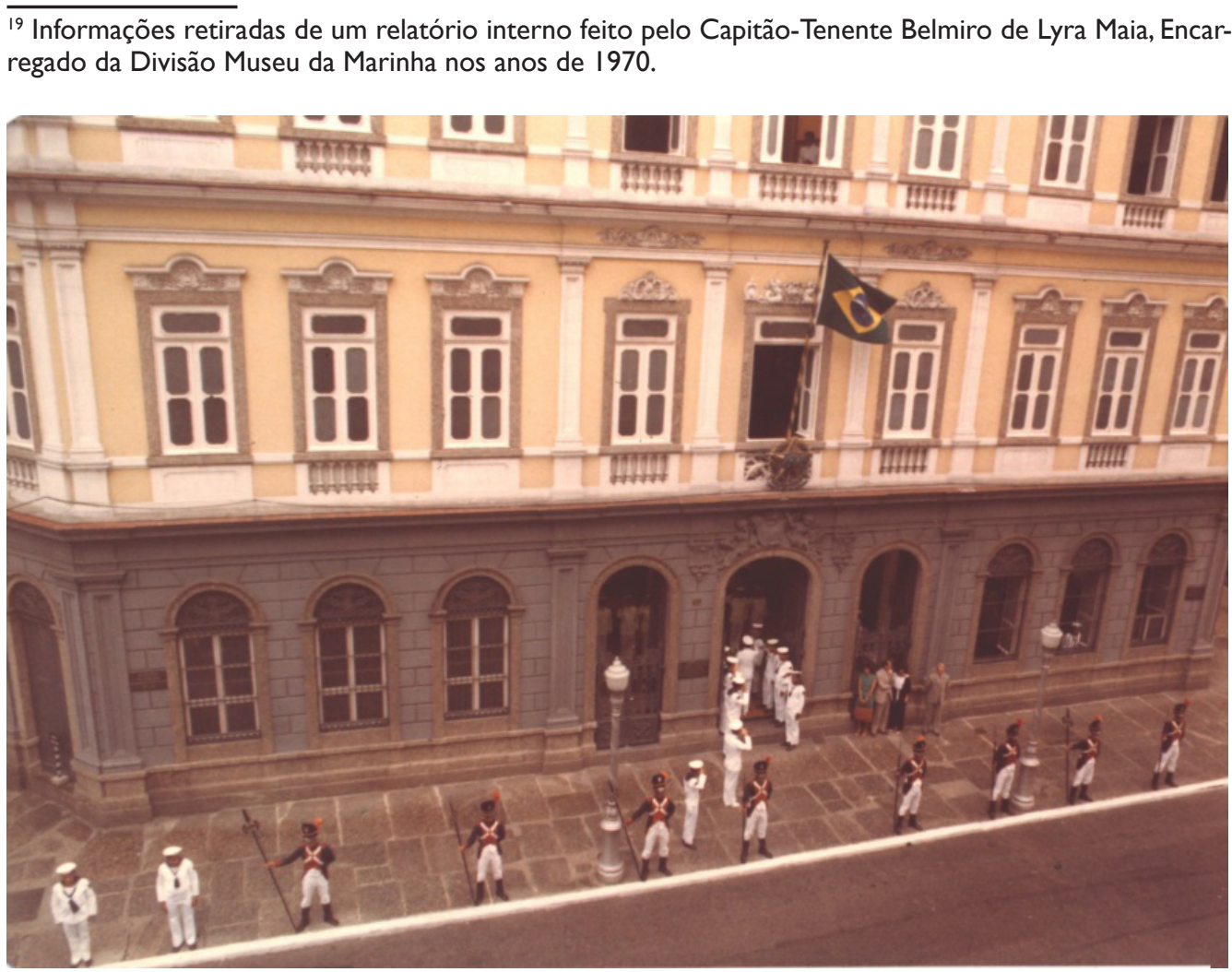

Figura 4 - Imagem do dia da reinauguração do Museu Naval e Oceanográfico em 1972.

Foto:Acervo: DPHDM - Arquivo da Marinha. 
tos de bordo, modelos de embarcações regionais, guerra contra Oribe e Rosas (I85I), Revolta da Armada, Primeira e Segunda Guerras Mundiais e chefes navais como Almirante Barroso, Almirante Soares Dutra, Almirante Saldanha, Almirante Frontin e Almirante Tamandaré (BRASIL, 197?).

A biblioteca contava com um acervo de 7.500 livros, abrangendo todos os campos da ciência, sendo a História do Brasil e da Armada os pontos fortes da coleção. O Arquivo contava com um acervo de 3.000 manuscritos (Relatórios de Guerras, documentação do pessoal militar e civil, mapas, livros internos das rotinas dos navios) (RIO DE JANEIRO, 1980). Em 1980, o prédio da Rua Dom Manuel I 5 recebe tombamento pelo Instituto Estadual do Patrimônio Cultural - INEPAC, sob o processo E-03/006.075/80.

Em 27 de dezembro de 1984, parte dos departamentos do SDGM foi transferida para a llha das Cobras $^{20}$, enquanto o Museu e o Departamento de Publicações permaneceram na Rua Dom Manuel (BRASIL, 2003). Com a ampliação do espaço, foi possível reestruturar o SDGM sediando, na Ilha das Cobras, os departamentos de Biblioteca,Arquivos, História Marítima e Administração. $\bigcirc$ SDGM volta à denominação anterior, tornando-se Serviço de Documentação da Marinha (SDM) em I 994 (BRASIL, 2003).

Em 200I, é iniciada a reforma do setor expositivo do Museu Naval e o acervo que lá estava em paióis (ou seja, depósitos) é transferido para uma área destinada à reserva técnica na llha Fiscal. A partir da revitalização do Museu Naval, iniciada em 200I, dispõe-se para o público de sete salas de exposição, além de espaço para um bistrô. Toda a área administrativa foi redimensionada e adaptada para o funcionamento do DPHCM, do Departamento de Museologia e do Departamento de Museus Navais (BRASIL, 2003).

Em setembro de 2006, é finalmente reinaugurado o Museu Naval (Figura 7), agora não mais oceanográfico, com sete salas de exposição que apresentam a exposição permanente "O Poder Naval na Formação do Brasil” (BRASIL, 2008). O tema destaca a participação do poder naval na História do Brasil e sua importância na formação do país até os dias atuais, pois o descobrimento, a colonização e a maioria das invasões e ameaças vieram do mar.

Em julho de 2008, o Serviço de Documentação da Marinha passou a Diretoria do Patrimônio Histórico e Documentação da Marinha e a Diretoria do Patrimônio Histórico e Cultural da Marinha foi extinta (BRASIL, 2008).

\section{Museu Oceanográfico do Instituto de Estudos do Mar Almirante Pau- lo Moreira ${ }^{21}$}

O Instituto de Estudos do Mar Almirante Paulo Moreira - IEAPM tem origem no início da década de 1970, quando o Projeto Cabo Frio 22 iniciado em I97I é instalado em Arraial do Cabo no ano de 1974. Tinha a intenção de ser uma universidade do mar produzindo conhecimentos oceanográficos, desenvol-

\footnotetext{
${ }^{20}$ Ilha situada na Baía da Guanabara que faz parte do complexo do Primeiro Distrito Naval no centro do Rio de Janeiro

${ }^{21}$ Disponível em:<https://www.marinha.mil.br/ieapm/museu>

22 “Projeto Cabo Frio, idealizado pelo Almirante Paulo de Castro Moreira da Silva, então Diretor do Instituto de Pesquisas da Marinha (IPqM). Em 1956, o então Capitão-de-Corveta Paulo Moreira montou um projeto de reconhecimento das condições de fertilização das águas ao largo da costa do Brasil que identificou, entre três áreas, a região fronteira ao Cabo Frio, influenciada pela Ressurgência, como interessante para o desenvolvimento de um empreendimento com o propósito, entre outros, de produzir proteínas a partir da riqueza natural dessas águas. O Projeto Cabo Frio, iniciado em I97I e instalado efetivamente em Arraial do Cabo em 1974.” Disponível em: https://www.marinha.mil.br/ieapm/node//8
} 


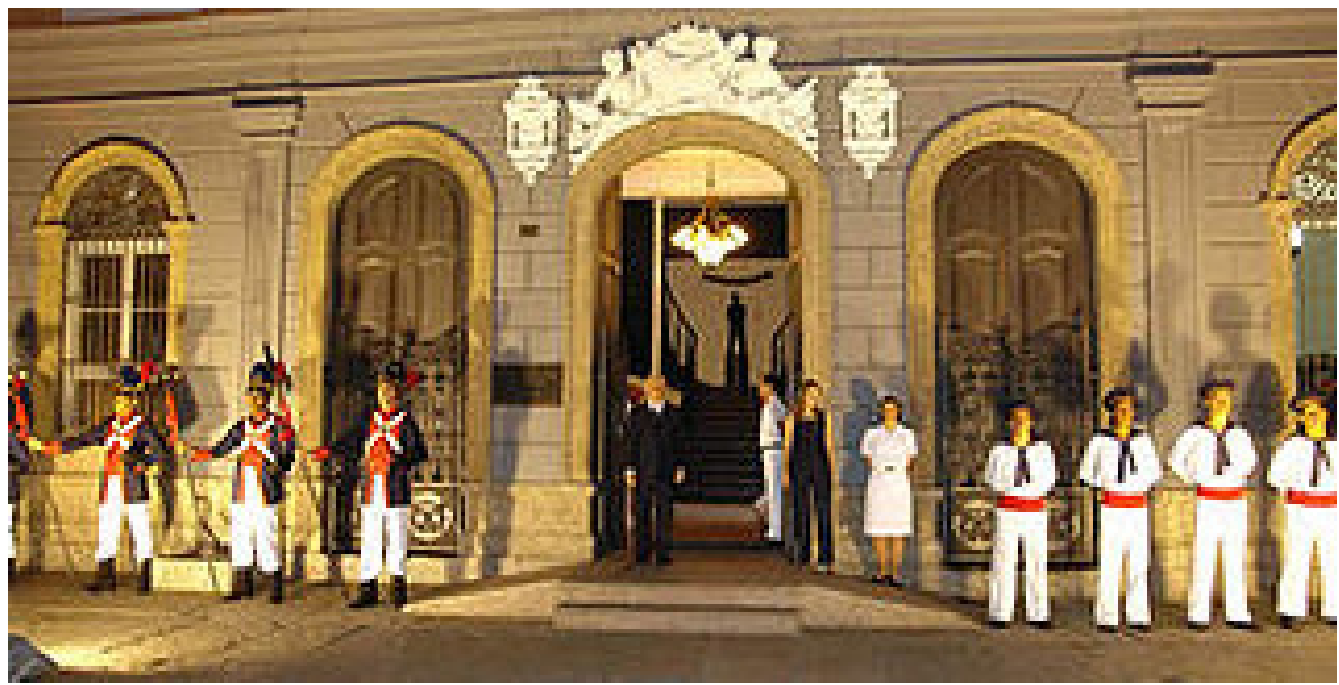

vimento da fertilização nas enseadas que fazem fronteira com Arraial do Cabo e produção auto-suficiente de gelo para a pesca local.

Hoje o IEAPM planeja e executa atividades de pesquisa e desenvolvimento científico e tecnológico nas áreas de oceanografia, meteorologia, hidrografia, geologia e geofísica marinhas, instrumentação oceanográfica, acústica submarina e engenharia costeira e oceânica (MELLO; LIMA, 2008).

No ano de 1982 começa a funcionar o museu oceanográfico: sua origem parte da idéia de expor o esqueleto de uma baleia Orca com seis metros de cumprimento que encalhara e morrera na llha do Cabo Frio no ano anterior.

O primeiro núcleo passa por reformas e, em 2000, ganha um anexo, funcionando assim o museu com dois prédios. $O$ acervo é composto por alguns objetos oriundos de naufrágios ocorridos na região, como a Fragata Thetys, esqueletos de peixes e modelos de animais marinhos que são objetos de estudo do IEAPM e aquários com espécies vivas.

\section{Museu da Aviação Naval da Base Aérea Naval de São Pedro da Aldeia}

O Museu da Aviação Naval da Base Aérea Naval de São Pedro da Aldeia foi criado em 23 de agosto de 2000. Seu objetivo é recolher e manter o acervo relativo à Aviação Naval, lançando mão da construção histórica onde está situado para trabalhar a consciência marítima no âmbito da MB e com a comunidade civil.

Seu acervo é composto por aeronaves originais e réplicas, motores diversos, maquetes, condecorações e medalhas, documentos e fotos ligados à história da aviação aeronaval e todas as atividades desenvolvidas pelos pilotos. O Museu está aberto ao público mediante agendamento.

As imagens das Figuras 8 e 9, a seguir, apresentam o prédio usado para a exposição e uma aeronave que está na parte externa do prédio.

\section{Espaço Memória Histórica da Diretoria de Hidrografia e Navegação ${ }^{23}$}

Instalado no andar térreo da Casa D'armas na Ponta da Armação em Ni-

${ }^{23}$ Disponível em:<https://www.mar.mil.br/dhn/dhn/quadros/visite_museu.html> 
terói, o Espaço Memória Histórica divulga as atividades realizadas pela Diretoria de Hidrografia e Navegação - DHN, bem como trabalha com a preservação dos vestígios materiais da memória das áreas relativas à Segurança da Navegação, à Hidrografia, à Sinalização Náutica, à Oceanografia, à Meteorologia e à Pesquisa Científica Antártica.

O circuito expositivo se apresenta dividido em seis módulos, que apresentam uma narrativa histórica do local, sobre a DHN, sobre a missão, sobre a cartografia, apresentando as fases de construção de uma carta náutica, demonstrando equipamentos usados para esse fim, a segurança da navegação e evidenciando a importância das atividades realizadas e por fim a contribuição do homem no mar e dos navios.

\section{Museu do Corpo de Fuzileiros Navais ${ }^{24}$}

Originário de uma sala de memórias inaugurada em 1974, o Museu do Corpo de Fuzileiros Navais recebe esta denominação em 1990 e passa a ocupar parte da área da histórica Fortaleza de São José na Ilha das Cobras, no centro da cidade do Rio de Janeiro.

Seu circuito expositivo está instalado em dois túneis que eram usados pelos portugueses, a partir do século XVII, como ligação entre as fortalezas ali erguidas. Um salão expõe o acervo relativo aos ex-Comandantes-Gerais do Corpo de Fuzileiros Navais e outros objetos. A Galeria de uniformes históricos está instalada em um outro antigo túnel. Na galeria da antiga Fortaleza estão painéis com monitores que narram a participação do Corpo de Fuzileiros $\mathrm{Na}$ vais em ações diversas. De forma geral, em suas salas o acervo histórico auxilia a narrativa da história do Corpo de Fuzileiros Navais e é composto por pinturas, esculturas, pratarias, resgates arqueológicos, medalhas, armamentos, uniformes, equipamentos, utensílios, viaturas e documentos em suporte papel. $\mathrm{Na}$ área externa, estão viaturas, motocicletas, metralhadoras e canhões oriundos do uso da corporação.Ali também está o monumento aos Fuzileiros Navais mortos em combate.

\section{Museu do Centro de Instrução Almirante Waldenkolk ${ }^{25}$}

O Centro de Instrução Almirante Waldenkolk - CIAW é a instituição da Marinha responsável pela formação de Oficias de diversos Corpos e Quadros, oferecendo cursos de formação, de Especialização e de Aperfeiçoamento em nível de pós-graduação. Está instalado na llha das Enxadas na Baía de Guanabara.

O Museu do CIAW funciona no prédio do comando. $O$ acervo existente é predominantemente composto por mobiliários em madeira (de diversos estilos), reproduções fotográficas e acervo pictórico variado, além de outros objetos tridimensionais relacionados à história da Instituição. Há ainda, grande quantidade de livros antigos em armários localizados próximo às salas destinadas ao Museu. A exposição está retratada na Figura II e apresenta os objetos, fotos e documentos sobre a Instituição.

\section{Sala de Memória do Centro de Instrução Almirante Graça Aranha ${ }^{26}$}

O Centro de Instrução Almirante Graça Aranha - CIAGA é a instituição responsável pelo Ensino Profissional Marítimo e atua na formação de todas as

${ }^{24}$ Disponível em:<https://www.marinha.mil.br/cgcfn/?q=museudocfn>

${ }^{25}$ Disponivel em:<https://www.marinha.mil.br/ciaw>

${ }^{26}$ Disponível em:<https://www.marinha.mil.br/ciaga/> 

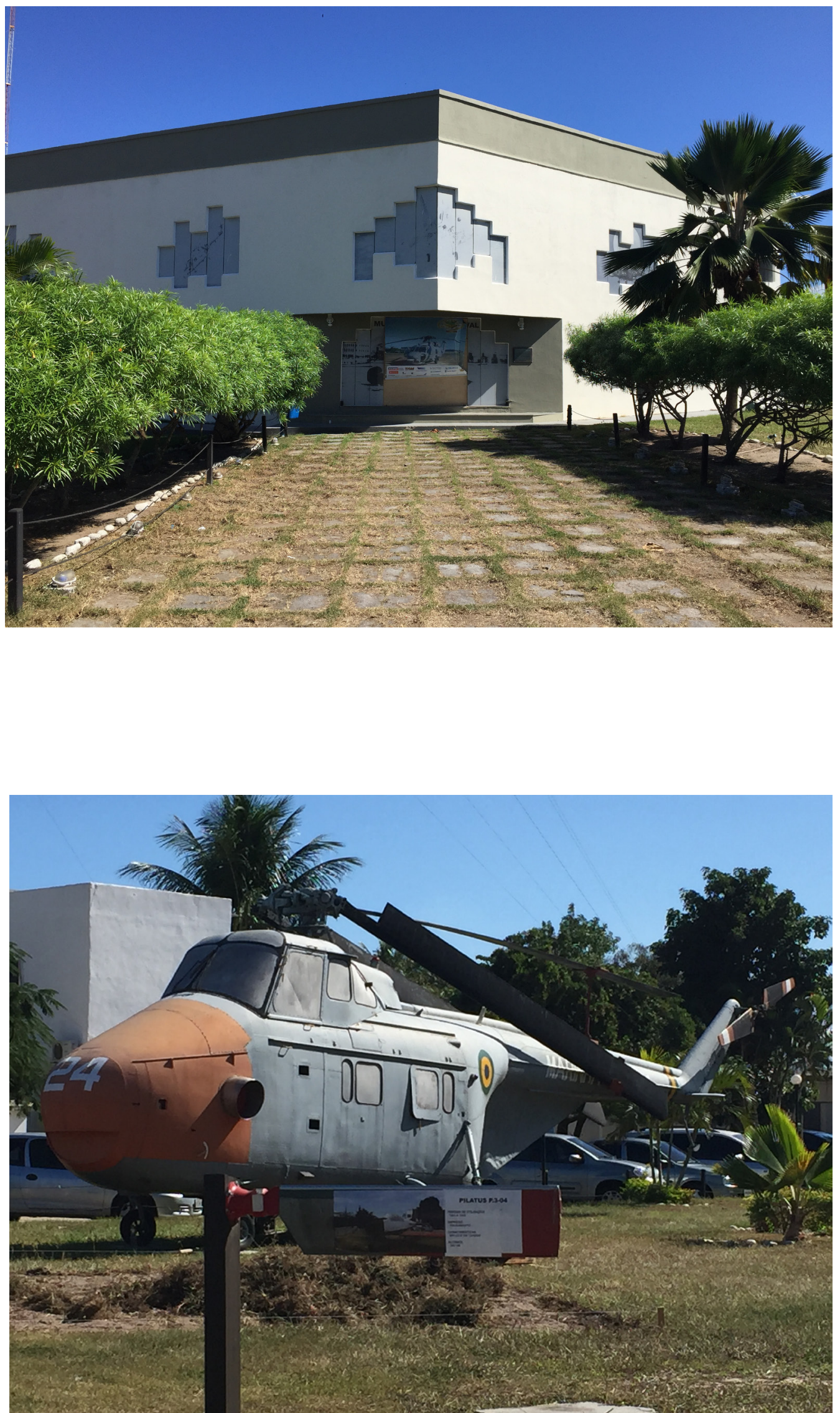

Figuras 8 e 9 - Imagem da entrada principal do prédio do Museu e de uma das aeronaves expostas. Foto:Acervo Departamento de Museologia - DPHDM - 2016 


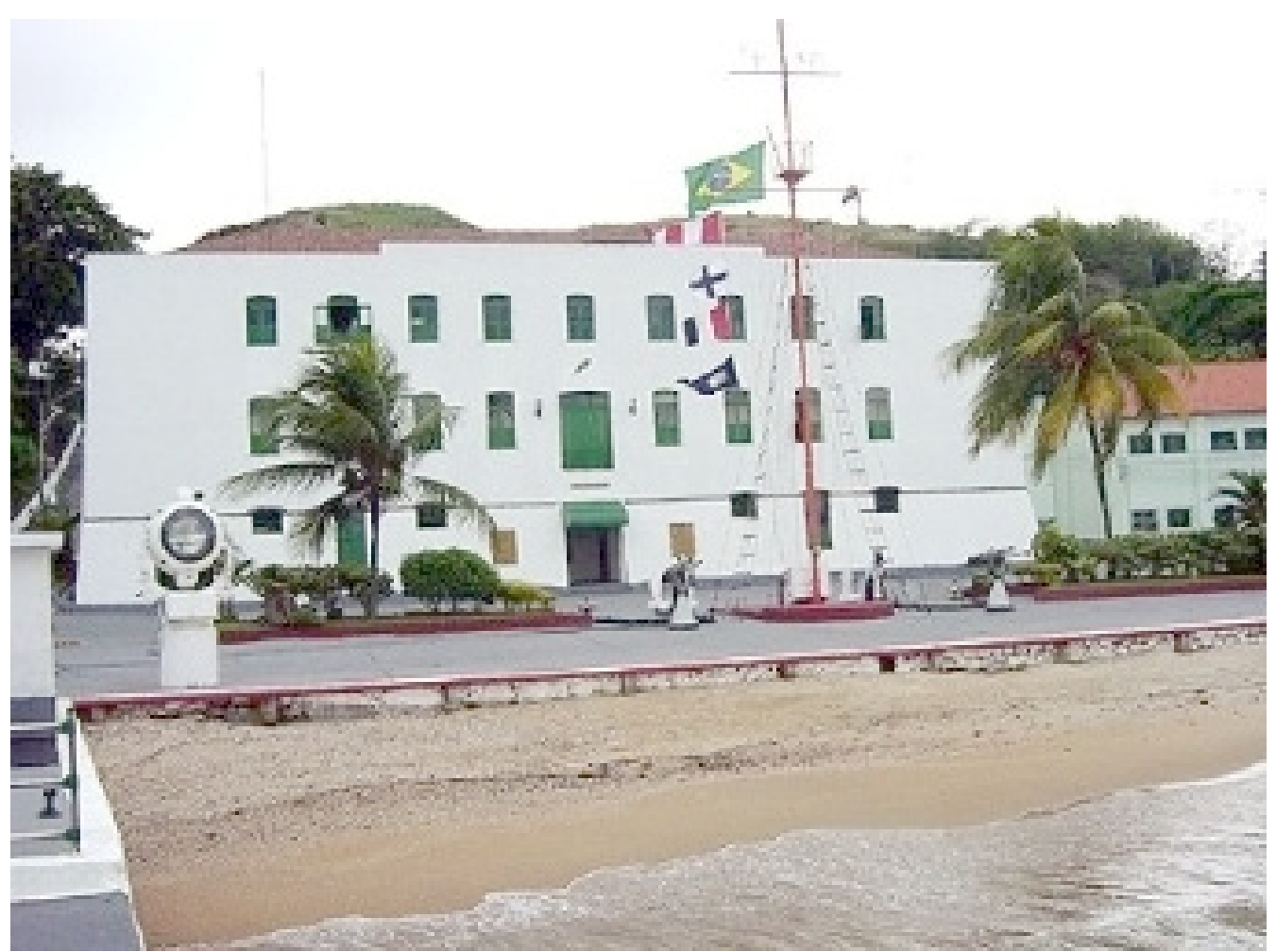

Figuras 10 - Imagem do prédio onde funciona e o Espaço Memória

Foto:Acervo da Diretoria de Hidrografia e Navegação, 2017

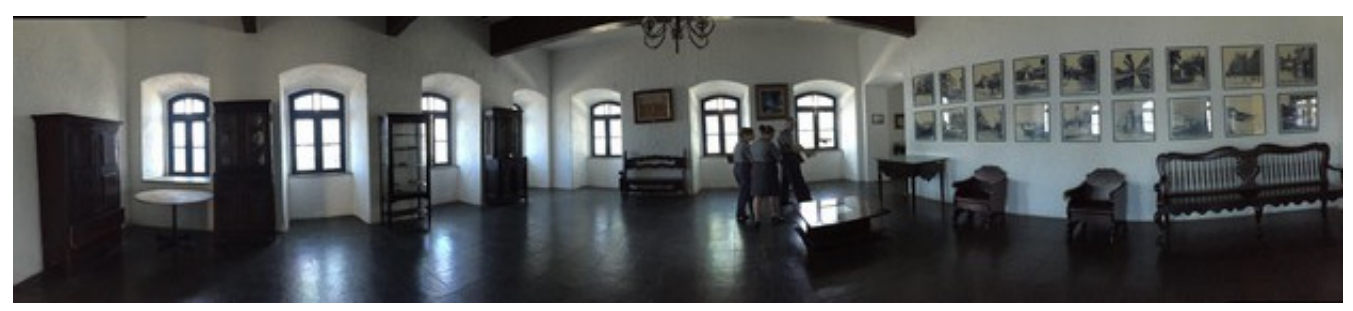

Figura II - Imagem panorâmica da área destinada à exposição.

Foto:Acervo Departamento de Museologia - DPHDM - 2016

categorias de pessoal que compõem a tripulação da frota mercante.

O Centro possui uma sala de memória localizada no salão de leitura dos alunos da Escola de Formação da Marinha Mercante ${ }^{27}$ - EFOMM, que funciona naquele local. Os objetos que compõem o acervo estão dispostos em vitrines horizontais, onde estão expostos documentos, objetos comemorativos, uniformes e outros artefatos que constroem uma narrativa sobre a história do CIAGA.

A imagem apresentada a seguir, na Figura 12, pode-se ter uma noção da área reservada com o acervo exposto.

$\overline{{ }^{27} \text { Parecer } n^{\circ} 10 / 2010}$, p. 3 


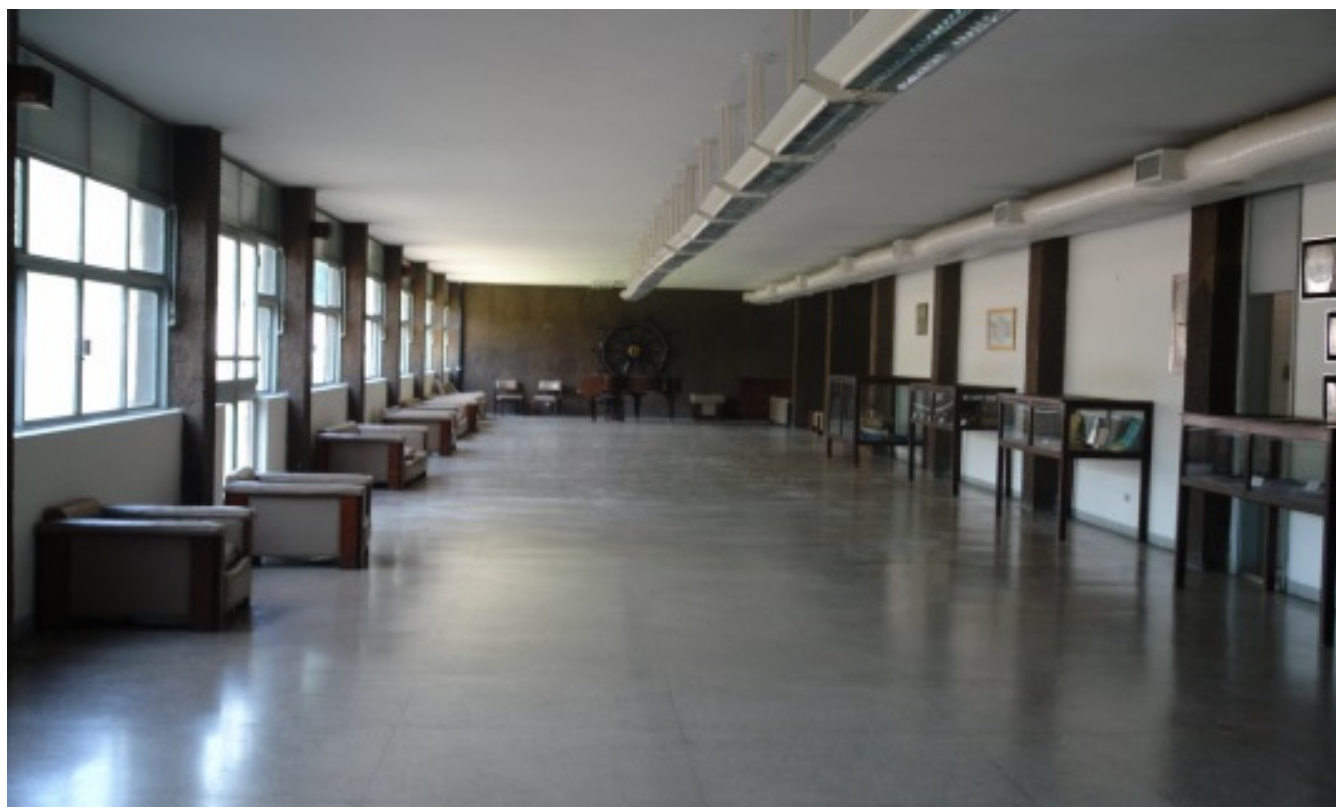

Figuras 12 - imagem da área destinada à exposição com vitrines. Foto:Acervo do Departamento de Museologia - DPHDM - 2010

\section{Considerações Finais}

A Marinha do Brasil, ao longo dos anos, tem desenvolvido mecanismos para conhecer e controlar os objetos que podem ser classificados como bens culturais e que estão sob sua guarda. Cada instituição tem seu desafio. Seja pecuniário ou de pessoal, mas verificou-se que existe uma preocupação no tocante aos objetos de valor histórico por parte dos gestores.

O suporte dos historiadores, cientistas e pesquisadores no âmbito da Marinha é de grande relevância durante o processo de construção da memória institucional incluindo objetos como fontes. Sua trajetória, seu desenvolvimento e seu uso formam um cabedal de informações que darão estrutura à historicidade, fornecendo uma identidade, um perfil, uma vida aos objetos.

Ao aprofundar a pesquisa nas instituições museológicas e de ensino se revelam objetos que darão suporte a construção da história de C\&T na Marinha do Brasil, permitindo entender a trajetória percorrida até chegar aos dias atuais, onde os órgãos responsáveis pela pesquisa utilizam tecnologia de ponta.

Os objetos que fazem dos acervos identificados ainda precisam ser explorados no sentido da pesquisa, tanto do lado da confecção, no que diz respeito ao material usado, quanto em alguns casos no lado da história do objeto: seu uso, trajetória, desdobramentos até chegar à musealização.

Os estudos sobre a coleção da DPHDM, com certeza a mais representativa, já caminharam alguns passos à frente das demais. Seus mais de 290 objetos de C\&T têm recebido ao longo dos últimos quinze anos, uma atenção no que concerne ás atividades técnico-museológica, que os colocam na vanguarda em relação aos outros acervos identificados.

Divulgar a importância dos acervos na Marinha do Brasil, discutir estratégias de preservação e exposição fará com que os objetos não sejam submetidos a um novo ciclo de apagamento, diminuindo o risco de perda, tão presente na vida destes equipamentos que formam parte dos vestígios materiais das ciências no Brasil. 


\section{REFERÊNCIAS}

ALMEIDA, Adilson José de. Acervos militares, museus e público. In: Comitê Internacional para Museus e Coleções de Armas e História Militar, I, 2008, Rio de Janeiro. Anais... Rio de Janeiro: DPHDM, 2008. p.65-7I.

APPELBAUM, Bárbara. Conservation Treatment Methodology. Oxford: Butterworth-Heinemann/Elsavier, 2007.

BITTENCOURT, Armando de Senna; LOUREIRO, Marcelo José. Patrimônio Histórico, Educação e Consciência Marítima. Revista Marítima Brasileira, Rio de Janeiro, v.132, p.9-22, out/dez, 2012. Disponível em: <www.revistamaritima.com. br/sites/defaut/files/rmb-4-12.pdf>. Acesso em: 20 out. 2017.

BRASIL. Constituição da República Federativa do Brasil: promulgada em 5 de outubro de 1988. . Disponível em: <http://www.senado.gov.br>. Acesso em: 20 out. 2017.

. Decreto ${ }^{\circ} 4.116$, de 14 de março de 1868. Cria um museu no Arsenal de Marinha da Corte. Disponível em: <http://www2.camara.leg.br/ legin/fed/decret/|824-|899/decreto-4 | |6-|4-marco-|868-553330-norma-pe.htm|> Acesso em: 10 out. 2017.

Decreto $n^{\circ} 6510$, de II de junho de 1907. Reorganiza a Biblioteca e o Museu da Marinha. Disponível em: <http://www2.camara.leg.br/ legin/fed/decret/I900-1909/decreto-6510-II-junho-1907-522742-republicacao-105596-pe. html>.Acesso em: 30 out. 2017.

Decreto $n^{\circ}$. 15.596, de 2 agosto de 1922, 1922. Criação do Museu Histórico Nacional. Disponível em:< http://www2.camara.leg.br/legin/fed/decret/1920-1929/ decreto-| 5596-2-agosto-| 922-568204-publicacaooriginal-9|597-pe.html>. Acesso 01 jun. 2017.

Ministério da Defesa. Portaria Interministerial MD/MEC $n^{\circ} 830$, de 23 de maio de 2008. Dispõe sobre a equivalência dos cursos de formação de oficiais das Forças Armadas. Disponível em: < http://www.portal.mec.gov.br/cne/arquivos/ pdf/2008/port 830_08.pdf >.Acesso em: 15 out. 2017.

Ministério da Defesa. Política Nacional de Defesa, 2012. Disponível em: < http:// www.defesa.gov.br/2012/mes07/pnd.pdf>.Acesso em: I0 out. 2017.

Normas Para Gestão de Bens Culturais. Secretaria-Geral da Marinha. Marinha do Brasil, Brasília, 29 de junho de 2004.

Normas Para Gestão de Bens Culturais. Secretaria-Geral da Marinha. Marinha do Brasil, Brasília, 30 de junho de 2009. 
Normas Para Gestão de Bens Culturais. Secretaria-Geral da Marinha. Marinha do Brasil, Brasília, 28 de fevereiro de 2012.

Normas Para Gestão de Bens Culturais. Secretaria-Geral da Marinha. Marinha do Brasil, Brasília, 27 de abril de 2015.

Regulamento da Diretoria do Patrimônio Histórico e Documentação da Marinha. Secretaria-Geral da Marinha do Brasil, Brasília, 3I de março de 2013.

CHERQUES, Sérgio. Dicionário do Mar. São Paulo: Globo, 1999. 55 Ip. il.

FERREIRA, Aurélio Buarque de Holanda. Dicionário Brasileiro da Língua Portuguesa. $6^{\text {a }}$ ed. Curitiba: Positivo, 1986. 895p.

FONSECA, Maria Cecília Londres. Referências Culturais: Base para novas políticas de patrimônio. Revista Políticas Sociais: Acompanhamento e Análise, n.2, p. I I I I20, 200I. Disponível em: <www.epea.gov.br/agencia/images/stories/PDFs/politicas sociais/referencia_2.pdf>. Acesso em: 20 out. 2017.

FROTA, Guilherme de Adrea. Colégio Naval 50 anos. Rio de Janeiro: Serviço de Documentação da Marinha, 200I. 100p. il.

GAMA, Edina Laura Nogueira da. O Poder Naval e a Formação do Brasil: breves reflexões sobre a historiografia naval brasileira e a modernização do Museu Naval. In: SIMPÓSIO NACIONAL DE HISTÓRIA - ANPUH, 27, 20I3, Natal. Anais... Natal, RN, 20I3. Disponível em: <http//: snh20I3.anpuh.org/resources/ anais/27//3646267_ARQUIVO _PoderNavalFormacaodoBrasil.pdf>. Acesso em: 30 out. 2017.

GUTIÉRREZ, Miguel ÁngelBonache. La conservación preventiva em laexposición permanente. Revista Ejército de TierraEspañol. Madri, año LXXI, n.83 I, p.32-40, 2010. Diponível em: <www.ejercito.mde.es/publicaciones/revistaejercito>.Acesso em: 20 out. 2017.

GRANJA, Pablo Gonzáles-Pola de La. El Patrimônio histórico militar em lá difusión de la cultura de seguridade e defensa. Cadernos de Estragegia Cultura de Seguridad Y Defensa. Instituto Espanhol de Estudios Estratégicos, n. I72. Madrid: Ministério da Defensa, 2015 Cap. IV. Catálogo General de publicaciones oficiales. Disponível em: < https://dialnet.unirioja.es/descarga/articulo/5122199.pdf>. Acesso em: 20 out. 2017.

HERNÁNDEZ, Francisca Hernándes. El discurso museológico enlosmuseos militares: génesis, conceptualización y narrativa museográfica. Revista de Museologia, n.37, p.08-26, 2006.

MELLO, Dick Silveira; LIMA, Tadeu de Mendonça Pereira. Museu Oceanográfico 
do IEAPM. Revista A Ressurgência, n.2, p. 30-33, ano 2008.

PINHEIRO, Lena Vania Ribeiro; GRANTO, Marcus. Para pensar a interdisciplinaridade na preservação: algumas questões preliminares. In: SILVA, Rubens Ribeiro Gonçalves da (Org.). Preservação Documental: uma mensagem para o futuro [on line]. Salvador: EDUBA, 20I2. p.23-40.

RIO DE JANEIRO. INEPAC. Tombamento do Serviço de Documentação da Marinha - Museu Naval, 1980. Disponível em: <http//:www.inepac.rj.gov.br/index.php/ bens_tombados/detalhar/ 250> Acesso em: I 3 ago. 2017.

RODRIGUES, Francisco Amado. Uma nova rede de museus para o Exército português. Dissertação (Mestrado), Programa de Pós-Graduação em Museologia, Faculdade de Letras da Universidade do Porto, Departamento de Ciências e Técnicas do Patrimônio, 2005.

STORI, Norberto; MARANHÃO, Romero de Albuquerque. Bens Culturais na Marinha do Brasil: um diálogo entre gestão e arte. Revista Mouseion, Canoas, n.25, p. 53-73, 2016.

TEIXEIRA. Mariana Jacob. A natureza e gestão das colecções dos museus militares na dependência da Direcção de História e Cultura Militar (Exército). Dissertação (Mestrado), Programa de Pós-Graduação em Museologia, Faculdade de Letras da Universidade do Porto, Departamento de Ciências eTécnicas do Patrimônio, $201 \mathrm{I}$. 